UDC 666.651

K.B. Podbolotov ${ }^{a}$, A.T. Volochko ${ }^{a}$, G.V. Lisachuk ${ }^{b}$, R.V. Krivobok ${ }^{b}$, V.V. Voloshchuk ${ }^{b}$

\title{
EXOTHERMIC SYNTHESIS OF CERAMIC MATERIALS BASED ON BARIUM AND STRONTIUM ALUMINOSILICATES
}

\author{
${ }^{a}$ Physical and Technical Institute of the National Academy of Sciences of Belarus, Minsk, Republic of \\ Belarus

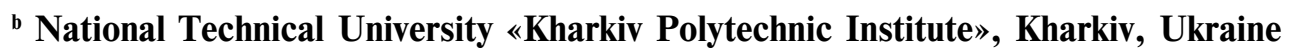

Ceramic materials were synthesized in the $\mathrm{RO}(\mathrm{R}=\mathrm{Ba}, \mathrm{Sr})-\mathrm{Al}_{2} \mathrm{O}_{3}-\mathrm{SiO}_{2}$ system using exothermic synthesis from solutions containing barium and strontium nitrates, silica and organic reducing agents (glycine and carbamide). It was shown that only the use of a mixture of glycine and carbamide as well as the addition of ammonium nitrate allows carrying out a complete exothermic synthesis with the formation of an X-ray amorphous product with a small fraction of the crystalline phase. It was established that monophase materials based on barium and strontium aluminosilicates $\left(\mathrm{BaAl}_{2} \mathrm{Si}_{2} \mathrm{O}_{8}\right.$ and $\left.\mathrm{SrAl}_{2} \mathrm{Si}_{2} \mathrm{O}_{8}\right)$ are formed when the obtained $\mathrm{X}$-ray amorphous product is heat-treated at the temperatures above $1000^{\circ} \mathrm{C}$. Ceramics from synthesized materials sintered at $1550^{\circ} \mathrm{C}$ has a high refractoriness, open porosity of $0-1.0 \%$, compressive strength of $115-120 \mathrm{MPa}$; dielectric constant of 3.25-6.0 (at the frequency of $1 \mathrm{MHz}$ ) and the loss tangent of $(1.5-5.2) \cdot 10^{-3}$. The results shows that the exothermic synthesis ensures the preparation of nano- and submicrocrystalline powders in the system $\mathrm{RO}(\mathrm{R}=\mathrm{Ba}, \mathrm{Sr})-\mathrm{Al}_{2} \mathrm{O}_{3}-\mathrm{SiO}_{2}$. Materials based on the obtained aluminosilicates can be used in the manufacture of protective structures for devices operating in the radio frequency band, in radar installations of aviation and rocket technology, in microwave elements, etc.

Keywords: radiotransparent ceramics, slavsonite, celsian, microstructure, dielectric constant, dielectric loss tangent.

DOI: $10.32434 / 0321-4095-2021-139-6-57-64$

\section{Introduction}

To protect the elements of the radio transmitting and receiving paths in aerospace, aviation and rocket technology, various organic (plastics, textolites, etc.) and inorganic (ceramics, glasses, glassceramics, etc.) radiotransparent materials are used. Inorganic materials are more promising for creating radiotransparent protective elements of electronic equipment structures as they are characterized by high uniformity of properties, heat resistance and radio transparency in a wide frequency range of radio frequencies. In particular, ceramic materials exhibit thermal stability and high heat resistance, which allows them to be used at high temperatures (up to $2000^{\circ} \mathrm{C}$ ) [1-5].

Radiotransparent materials are dielectrics that do not change the amplitude of the electromagnetic wave passing through them and do not cause a chaotic change in its phase. The transparency of these materials for radio waves means that they have very small dielectric losses in the range of operating temperatures and practically do not reflect radio waves [5].

The main materials for antenna fairings of aircraft and radiotransparent elements of various designs are radio-transparent materials based on quartz [1-5], silicon nitride $[1,3-4]$ and $\mathrm{RO}-\mathrm{Al}_{2} \mathrm{O}_{3}-\mathrm{SiO}_{2}$ systems (where $\mathrm{R}=\mathrm{Li}_{2}, \mathrm{Na}_{2}, \mathrm{Mg}, \mathrm{Ca}, \mathrm{Sr}, \mathrm{Ba}, \mathrm{Zn}$ ) [1-6]. In addition, these types of ceramics are widely used in the manufacture of technical ceramic products (capacitors, inductors, electrical insulators, etc.) operating at elevated frequencies.

Comparative characteristics of compounds for producing ceramic radiotransparent materials and products are presented in Table $1[5,7-10]$. Analysis of physical-mechanical, thermophysical and electrophysical properties allows us to conclude that it is advisable to fabricate radiotransparent ceramic materials based on aluminosilicates in the $\mathrm{RO}-\mathrm{Al}_{2} \mathrm{O}_{3}-\mathrm{SiO}_{2}(\mathrm{R}=\mathrm{Ba}, \mathrm{Mg}, \mathrm{Sr})$ systems by directed 
Table 1

Characteristics of compounds with a set of properties required for radio-transparent ceramics

\begin{tabular}{c|c|c|c|c|c|c|c}
\hline Compound & Formula & $\begin{array}{c}\text { Coefficient of linear } \\
\text { thermal expansion, } \\
\times 10^{6}, \mathrm{deg}^{-1}\end{array}$ & $\begin{array}{c}\text { Apparent } \\
\text { density, } \\
\mathrm{g} \mathrm{cm}^{-3}\end{array}$ & $\begin{array}{c}\text { Melting point, } \\
{ }^{0} \mathrm{C}\end{array}$ & $\begin{array}{c}\text { Mohs } \\
\text { hardness }\end{array}$ & $\begin{array}{c}\text { Dielectric } \\
\text { constant, } \varepsilon\end{array}$ & $\begin{array}{c}\text { Dielectric loss } \\
\text { tangent, } \\
\text { tg } \delta \cdot 10^{3}\end{array}$ \\
\hline $\begin{array}{c}\text { Quartz } \\
\text { ceramics }\end{array}$ & $\mathrm{SiO}_{2}$ & 0.6 & $1.94-2.05$ & $\begin{array}{c}>1300 \\
\text { (softening) }\end{array}$ & 7.0 & $3.3-3.5$ & $0.1-0.3$ \\
\hline Mullite & $\mathrm{Al}_{6} \mathrm{Si}_{2} \mathrm{O}_{13}$ & 6.2 & $3.00-3.10$ & 1810 & 6.0 & 7.0 & $0.5-1.0$ \\
\hline Willemite & $\mathrm{Zn}_{2} \mathrm{SiO}_{4}$ & 3.2 & $3.90-4.10$ & 1512 & $5.0-6.0$ & 5.5 & $0.2-2.0$ \\
\hline Spodumene & $\mathrm{LiAlSi}_{2} \mathrm{O}_{6}$ & 0.9 & $3.10-3.20$ & 1425 & $6.5-7.0$ & $8.5-9.0$ & $7.0-20.0$ \\
\hline Cordierite & $\mathrm{Mg}_{2} \mathrm{Al}_{4} \mathrm{~S}_{5} \mathrm{O}_{18}$ & 2.6 & $2.55-2.75$ & 1460 & $6.0-6.5$ & $4.0-7.0$ & $0.5-3.0$ \\
\hline Anorthite & $\mathrm{CaAlSi}_{2} \mathrm{O}_{8}$ & 6.1 & $2.72-2.75$ & 1550 & $6.0-6.5$ & $6.0-7.0$ & $0.2-3.0$ \\
\hline Slavsonite & $\mathrm{SrAl}_{2} \mathrm{Si}_{2} \mathrm{O}_{8}$ & 6.5 & 3.27 & 1765 & $6.0-6.5$ & $6.0-7.0$ & $1.1-5.0$ \\
\hline Celsian & $\mathrm{BaAl}_{2} \mathrm{Si}_{2} \mathrm{O}_{8}$ & 2.7 & $3.10-3.40$ & 1740 & $6.0-6.5$ & $6.5-7.0$ & $0.1-3.0$ \\
\hline Corundum & $\mathrm{Al}_{2} \mathrm{O}_{3}$ & 7.5 & $3.7-3.9$ & 2050 & 9.0 & $9.0-10.0$ & $0.1-2.0$ \\
\hline
\end{tabular}

synthesis of celsian, cordierite, or strontium anorthite, which have a set of necessary characteristics.

The effect of the structure on the physical and mechanical properties of a monophase ceramic is mainly associated with the dispersion of the crystalline phase: the strength of the material decreases with an increase in the grain size. At the same time, the dielectric properties are mainly associated with the purity and homogeneity of the monophase material and, in the case of polyphase ceramics and composite materials, with the uniformity of the dispersed crystalline phase distribution, which ensures the constancy of properties over the volume of the material. Thus, one of the most significant factors in the manufacture of ceramic is the homogeneity of the material, which requires thorough mixing of the components of the raw material composition.

To carry out the synthesis of ceramic based on $\mathrm{RO}-\mathrm{Al}_{2} \mathrm{O}_{3}-\mathrm{SiO}_{2}$ systems (where $\mathrm{R}=\mathrm{Ba}, \mathrm{Sr}$, and $\mathrm{Zn}$ ), the method of solid-phase synthesis from oxides, carbonates and natural compounds is currently used [11-14]. The use of natural compounds introduces impurities that deteriorate the electrophysical characteristics of materials. In addition, it is necessary to carry out burning at high temperatures to obtain the target phase when using the solid-phase synthesis method.

One of the promising and developing methods for preparing ceramic materials in the nanocrystalline state is an exothermic synthesis from solutions, which uses the internal energy of the system. The advantages of the exothermic synthesis from solutions are as follows: the possibility of producing pure ceramics with minimal impurities, a decrease in the size of crystalline formations due to the intensive gas evolution during the synthesis and a short exposure time to high temperatures, and the creation of unique temperature-time conditions for the synthesis, which promote the formation of new crystalline and amorphous phases.

The aim of this work is to synthesize and study ceramic barium and strontium aluminosilicate materials by using the exothermic synthesis from solutions of organic-salt compositions.

\section{Experimental}

As initial components, we used chemically pure barium, strontium, aluminum and ammonium nitrates $\left(\mathrm{Ba}\left(\mathrm{NO}_{3}\right)_{2}, \mathrm{Sr}\left(\mathrm{NO}_{3}\right)_{2}, \mathrm{Al}\left(\mathrm{NO}_{3}\right)_{3} \cdot 9 \mathrm{H}_{2} \mathrm{O}\right.$, $\left.\mathrm{NH}_{4} \mathrm{NO}_{3}\right)$, as well as silicon oxide $\left(\mathrm{SiO}_{2}\right.$, aerosil A-300). Carbamide $\left(\mathrm{CH}_{4} \mathrm{~N}_{2} \mathrm{O}\right)$ and glycine $\left(\mathrm{C}_{2} \mathrm{H}_{5} \mathrm{NO}_{2}\right)$ were used as organic components.

In general, the reaction of preparation of barium, strontium and aluminum oxides $(\mathrm{Me}-\mathrm{Ba}$, $\mathrm{Sr}$, and $\mathrm{Al}$ ) with the participation of these components can be written as follows:

$$
\begin{aligned}
& \mathrm{Me}^{\vartheta}\left(\mathrm{NO}_{3}\right)_{\vartheta}+\left(\frac{5}{6} \vartheta \varphi\right) \mathrm{CH}_{4} \mathrm{~N}_{2} \mathrm{O}+ \\
& +\vartheta \frac{5}{4}(\varphi-1) \mathrm{O}_{2}=\mathrm{Me}^{\vartheta} \mathrm{O}_{\frac{\vartheta}{2}}+\left(\frac{5}{6} \vartheta \varphi\right) \mathrm{CO}_{2}+ \\
& +\vartheta\left(\frac{5 \varphi+3}{6}\right) \mathrm{N}_{2}+\left(\frac{10}{6} \vartheta \varphi\right) \mathrm{H}_{2} \mathrm{O}
\end{aligned}
$$

$$
\begin{aligned}
& \mathrm{Me}^{\vartheta}\left(\mathrm{NO}_{3}\right)_{\vartheta}+\left(\frac{5}{9} \vartheta \varphi\right) \mathrm{C}_{2} \mathrm{H}_{5} \mathrm{NO}_{2}+ \\
& +\vartheta \frac{5}{4}(\varphi-1) \mathrm{O}_{2}=\mathrm{Me}^{\vartheta} \mathrm{O}_{\frac{\vartheta}{2}}+\left(\frac{10}{9} \vartheta \varphi\right) \mathrm{CO}_{2}+ \\
& \vartheta\left(\frac{5 \varphi+9}{18}\right) \mathrm{N}_{2}+\left(\frac{25}{18} \vartheta \varphi\right) \mathrm{H}_{2} \mathrm{O}
\end{aligned}
$$


where $\varphi$ is the ratio of the reducing agent to the oxidizing agent, and $\vartheta$ is the metal valence.

The ratio of the reducing agent to the oxidizing agent is defined as the ratio of the actual reducing agent/oxidizing agent ratio to the stoichiometric reducing agent/oxidizing agent ratio. So, $\varphi=1$ corresponds to stoichiometry and the supply of atmospheric oxygen is not required to complete the oxidation in this case. The inequality $\varphi>1($ or $<1)$ corresponds to the case of excess (or deficiency) of the reducing agent. In the case of $\varphi>1$, a reducing atmosphere is formed from the products of incomplete oxidation of the reducing agent, which contributes, in the case of metal synthesis, to the production of pure metal under normal conditions (without specially created reducing or inert atmosphere).

In the course of the exothermic reaction, the resulting oxides $\mathrm{BaO}, \mathrm{SrO}, \mathrm{Al}_{2} \mathrm{O}_{3}$ and silicon oxide interact with the formation of aluminosilicates:

$$
\mathrm{MeO}+\mathrm{Al}_{2} \mathrm{O}_{3}+\mathrm{nSiO}_{2}=\mathrm{MeO} \cdot \mathrm{Al}_{2} \mathrm{O}_{3} \cdot \mathrm{nSiO}_{2} .
$$

The compositions for the synthesis were calculated based on the above synthesis reactions, taking into account the composition of the target compositions (Table 2) and the ratio of the reducing agent to the oxidizing agent $\varphi=1.25$.

Table 2

Phase compositions and oxide compositions

\begin{tabular}{c|c|c|c|c|c}
\hline \multirow{2}{*}{ Number } & Phase composition, & \multicolumn{4}{|c}{ Content of oxides, mol.\% } \\
\cline { 3 - 6 } & wt.\% & $\mathrm{BaO}$ & $\mathrm{SrO}$ & $\mathrm{Al}_{2} \mathrm{O}_{3}$ & $\mathrm{SiO}_{2}$ \\
\hline $\mathrm{C}-1$ & $\mathrm{BaAl}_{2} \mathrm{Si}_{2} \mathrm{O}_{8}-100$ & 25.0 & 0.0 & 25.0 & 50.0 \\
\hline $\mathrm{S}-1$ & $\mathrm{SrAl}_{2} \mathrm{Si}_{2} \mathrm{O}_{8}-100$ & 0.0 & 25.0 & 25.0 & 50.0 \\
\hline $\mathrm{CS}-11$ & $\mathrm{BaAl}_{2} \mathrm{Si}_{2} \mathrm{O}_{8}-50$ & 12.1 & 12.9 & 25.0 & 50.0 \\
\cline { 5 - 7 } & $\mathrm{SrAl}_{2} \mathrm{Si}_{2} \mathrm{O}_{8}-50$ & & & \\
\hline
\end{tabular}

To prepare the solution, the components were weighed and transferred with simultaneous stirring into a heat-resistant glass with water, which was heated to the temperature of $60-80^{\circ} \mathrm{C}$ to improve dissolution. Silica was preliminarily wetted with alcohol and then added to the resulting solution of the components under continuous stirring. Then, the solution was homogenized by stirring it for 25$30 \mathrm{~min}$.

The initiation of the synthesis process was carried out by thermal treatment of a solution of the components (dry gel) pre-dried at $80^{\circ} \mathrm{C}$ in an oven at the temperature of $500^{\circ} \mathrm{C}$.

In general, the synthesis process can be described in the following way. After placing the solution in the furnace, the solution is heated and water is removed with the formation of a gel-like structure from organic components with silica particles and nitrates distributed in it, which then foams. With a further increase in temperature, the foam ignites and its combustion is accompanied by a bright glow. After the end of the combustion reaction, the resulting material has a foam-like, spongy and highly porous structure.

The powders obtained as a result of the synthesis were subjected to the heat treatment in a laboratory furnace at the temperatures of $1000-1200^{\circ} \mathrm{C}$ to determine changes in the phase composition with holding at the maximum temperature for $1 \mathrm{~h}$.

To prepare sintered ceramic samples, the powders obtained after heat treatment at $1000^{\circ} \mathrm{C}$ were milled in a wet ball mill in an aqueous medium for $8 \mathrm{~h}$. From the obtained powders using a binder (polyvinyl acetate solution), a compacted powder was prepared and the samples were pressed in the form of a cylinder. The samples were sintered at the temperatures of $1250-1550^{\circ} \mathrm{C}$.

$\mathrm{X}$-ray phase analysis of the synthesis products was carried out on an Al-27 mini diffractometer using a copper $\mathrm{Cu}-\mathrm{K}_{\alpha}$ cathode. The international card index PDF-2 (2004) and the HighScorePlus software were used to identify crystalline phases.

The study of the microstructure was carried out using a TescanMira 3 scanning electron microscope equipped with an OxfordIns electron probe local chemical analysis system.

The determination of the density and porosity of the material was carried out according to the state standard GOST 2409 by the method of hydrostatic weighing. The mechanical strength in compression was determined on a ZD-10 testing machine in accordance with the state standard GOST 473.6. The determination of the electrophysical characteristics of the samples was carried out using an E7-20 immittance meter in the frequency range of $500 \mathrm{~Hz}$ to $1 \mathrm{MHz}$ at the temperature of $20^{\circ} \mathrm{C}$.

\section{Results and discussion}

Visual observation of the course of the synthesis process showed that the initiation of the combustion process does not occur when carbamide is used. When glycine is used, the synthesis reaction proceeds in a low-intensity smoldering mode.

According to the data of X-ray phase analysis, the formation of phases of barium and strontium aluminosilicates (Fig. 1,a) does not occur in the case of using carbamide as a reducing agent. The phase composition is represented by barium and strontium nitrates as well as oxides and carbonates, which indicates an insufficient temperature of the process and is associated with a low intensity of the reaction 


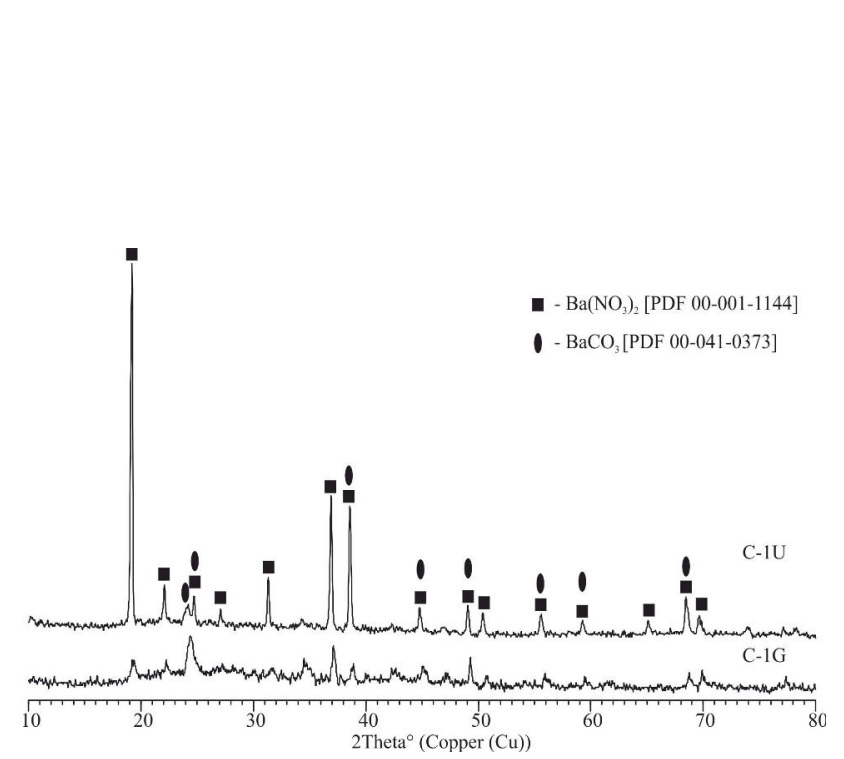

a

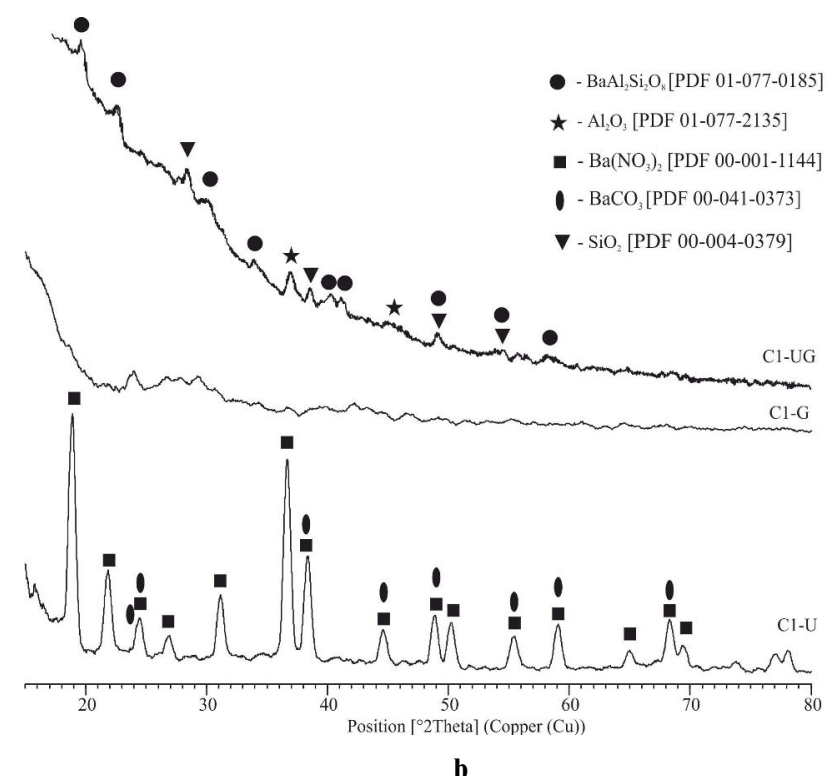

b

Fig. 1. XRD patterns of the synthesized materials based on the barium aluminosilicate system without ammonium nitrate (a) and with the addition of ammonium nitrate (b). The following compositions were used as a reducing agent: C1-U - carbamide; C1-G - glycine; C1-UG - carbamide and glycine at the ratio of 1:1

of exothermic synthesis. When glycine is used, the reaction with barium nitrate also does not provide the formation of the necessary phases of aluminosilicates. However, when using strontium, the intensity of the process increases and the formation of the phases of carbonates and strontium oxides is observed in small amounts. In addition, an $\mathrm{X}$-ray amorphous phase is formed, which, apparently, consists of aluminosilicates. When glycine is used, the powder of the material has a black-brown color, which is apparently due to the presence of carbon and products of incomplete decomposition of organic substances.

It follows from the experimental results that the synthesis process in barium- and strontiumcontaining systems is low-exothermic and an increase in heat release during the reaction interaction is required. To this end, it is possible to use additives that can exothermically interact with the components of the mixture. However, it is necessary to ensure the absence of impurities in the resulting material. These conditions are met for ammonium nitrate, which is capable of exothermic interaction with organic compounds and is completely decomposed at high temperatures. In addition, a reducing agent has a strong effect on the synthesis process; quite often, the combination of reducing agents increases the exothermic effect and accelerates the process. An increase in the content of the additive and the combination of reducing agents were carried out by using a barium-containing system (compositions C1 ), since in this system the synthesis process is the least exothermic due to the high thermal stability of barium nitrate. Ammonium nitrate was introduced in a ratio of $1 \mathrm{~mol} \mathrm{NH}_{4} \mathrm{NO}_{3}$ to $1 \mathrm{~mol}$ of the total oxides $\left(\sum_{\mathrm{vEyOX}}\right)$ to obtain the barium aluminosilicate phase at $\varphi=1.25$. The method for preparing the solution is similar to that for compositions without ammonium nitrate.

Evaluation of the combustion intensity of the compositions showed that the highest combustion intensity, which is expressed in the maximum brightness of the glow in the combustion wave and the appearance of an open flame above the surface of the mixture, was detected in the cases of the compositions containing glycine and carbamide at a ratio of 1:1 (50:50). Figure 1,b shows the XRD patterns of a mixture containing glycine and carbamide in equal molar fractions. In this case, the formation of the crystalline phase of barium aluminosilicate $\mathrm{BaAl}_{2} \mathrm{Si}_{2} \mathrm{O}_{8}$ is observed. According to $\mathrm{X}$-ray structural analysis, the crystallite size is 13-15 $\mathrm{nm}$. At the same time, the presence of silicon and aluminum oxides is also noted as well as a high degree of amorphization of the resulting material.

The materials synthesized in strontium- and barium-strontium-containing systems with the addition of ammonium nitrate and a mixture of reducing agents (carbamide and glycine), as shown by X-ray phase analysis data, are completely X-ray amorphous. This indicates that a product with either a glassy structure or a crystallite size of less than $2 \mathrm{~nm}$ is formed.

In order to complete the process of phase 


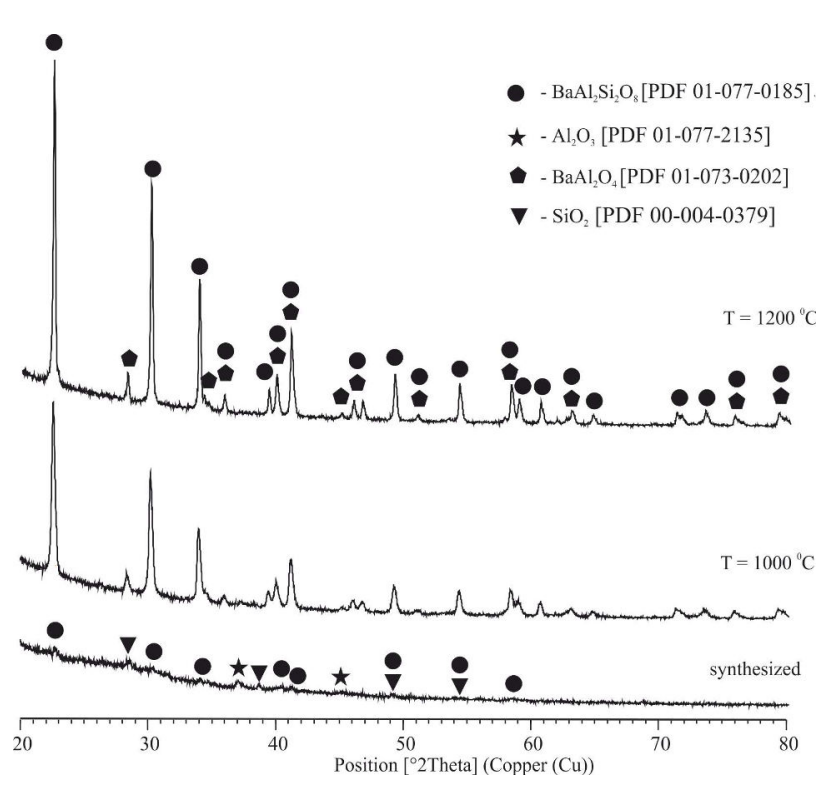

a

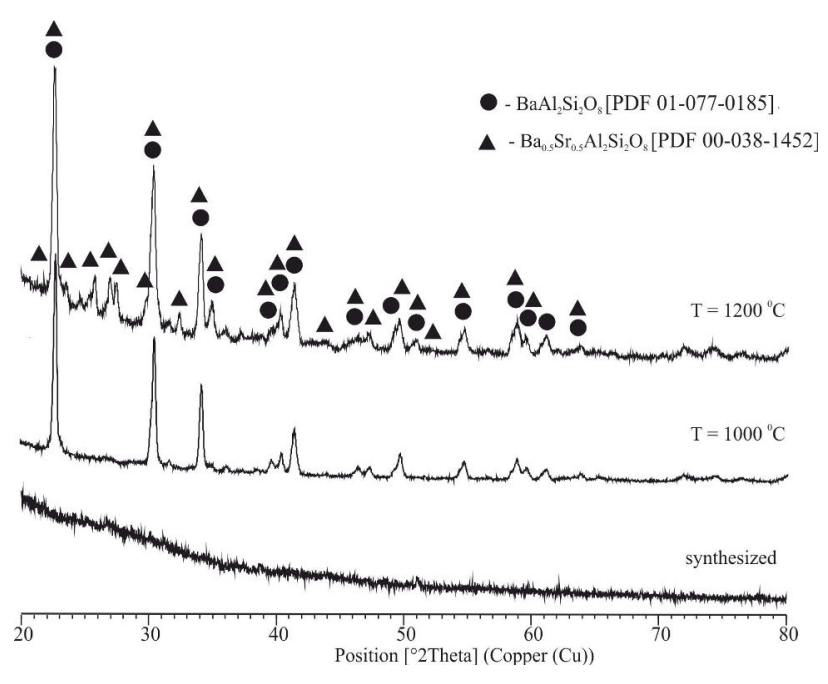

b

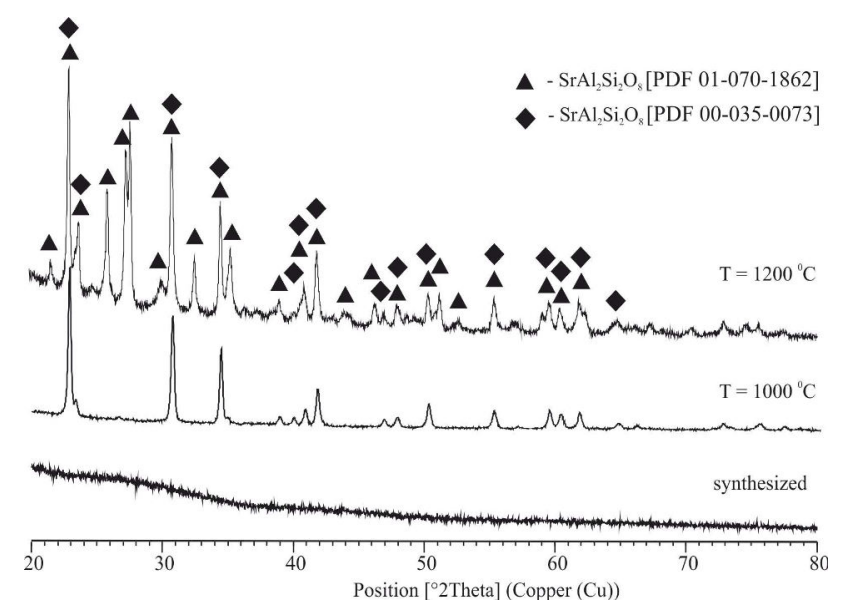

c

Fig. 2. Phase composition of the synthesized and calcined materials obtained from the flowing compositions:

$$
\mathrm{a}-\mathrm{C}-1 ; \mathrm{b}-\mathrm{CS}-11 \text { and } \mathrm{c}-\mathrm{S}-1
$$

formation, crystallization and removal of possible impurities of organic compounds, the resulting powders were calcined in air at temperatures of 1000$1200^{\circ} \mathrm{C}$. The phase composition of materials is shown in Fig. 2.

As can be seen from the presented data, the process of phase formation and crystallization is completed during heat treatment. At the same time, a high purity of the obtained materials is achieved with a main phase content of more than $95 \%$.

The microstructure of the powder obtained after heat treatment of the barium aluminosilicate composition $(\mathrm{C}-1)$ at $1000^{\circ} \mathrm{C}$ is shown in Fig. 3.

The structure is represented by a highly porous foam-like substance with various sizes of crystalline aggregates of irregular shape. The crystallite size is
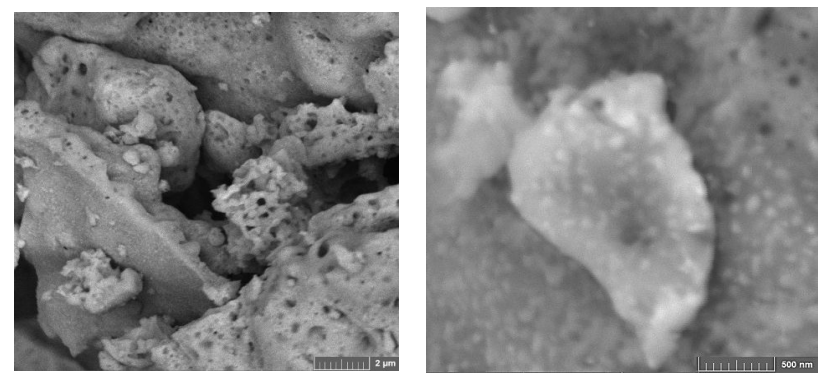

Fig. 3. Microstructure of the material obtained from the composition $\mathrm{C}-1 \mathrm{~N}$ after heat treatment at the temperature of $1000^{\circ} \mathrm{C}$

about $20-50 \mathrm{~nm}$.

Samples in the form of cylinders were prepared from the synthesized powders calcined at $1000^{\circ} \mathrm{C}$ by 

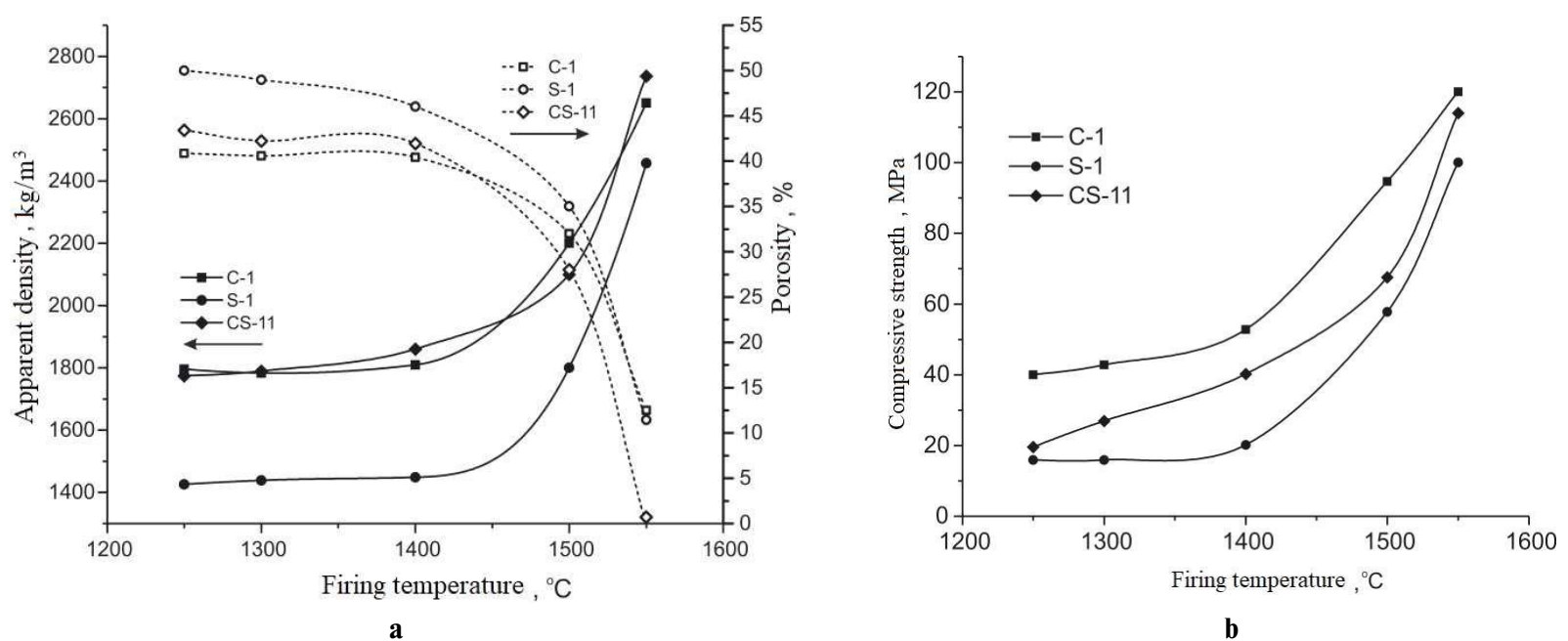

Fig. 4. Dependence of porosity density (a) and compressive strength of the obtained samples (b) on the firing temperature

the method of semi-dry pressing. These samples were used in the study of physicochemical characteristics. The main properties of the samples depending on the burning temperature are shown in Fig. 4.

The dependence of the characteristics of synthesized materials on the firing temperature shows that the formation of a material with minimum porosity in the $\mathrm{RO}(\mathrm{R}=\mathrm{Ba}, \mathrm{Sr})-\mathrm{Al}_{2} \mathrm{O}_{3}-\mathrm{SiO}_{2}$ system is observed at a high temperature $\left(1550^{\circ} \mathrm{C}\right)$. At this temperature, the highest degree of sintering is characteristic of the material obtained on the basis of the composition CS-11; the open porosity is $0-1.0 \%$ and the compressive strength is $115 \mathrm{MPa}$. Compositions $\mathrm{C}-1$ and $\mathrm{S}-1$ sintered at this temperature have an open porosity of the order of $11-12 \%$. Such a high sintering temperature is possibly associated with the minimum amount of impurities and the monophasic nature of the material. XRD patterns of a thin section of the surface of sintered samples showed the presence of pure phases, similar to powders after calcination at $1200^{\circ} \mathrm{C}$. Sintering at temperatures $\leq 1400^{\circ} \mathrm{C}$ apparently proceeds by a diffusion mechanism, and only in the region of high temperatures $\left(\geq 1500^{\circ} \mathrm{C}\right)$ the amount of the formed liquid phase becomes sufficient to change the sintering mechanism to a liquid phase with a significant acceleration of the material compaction.

The results of the studies of electrophysical characteristics of the samples are shown in Fig. 5 and Table 3.

Table 3

Electrophysical characteristics of the samples at $1 \mathrm{MHz}$

\begin{tabular}{l|c|c|c}
\hline \multirow{2}{*}{ Characteristic } & \multicolumn{3}{|c}{ Value } \\
\cline { 2 - 4 } & C-1 & S-1 & CS-11 \\
\hline Dielectric constant, $\varepsilon$ & 3.25 & 4.55 & 5.72 \\
\hline Dielectric loss tangent, $\operatorname{tg} \delta \cdot 10^{3}$ & 5.20 & 1.47 & 2.17 \\
\hline
\end{tabular}

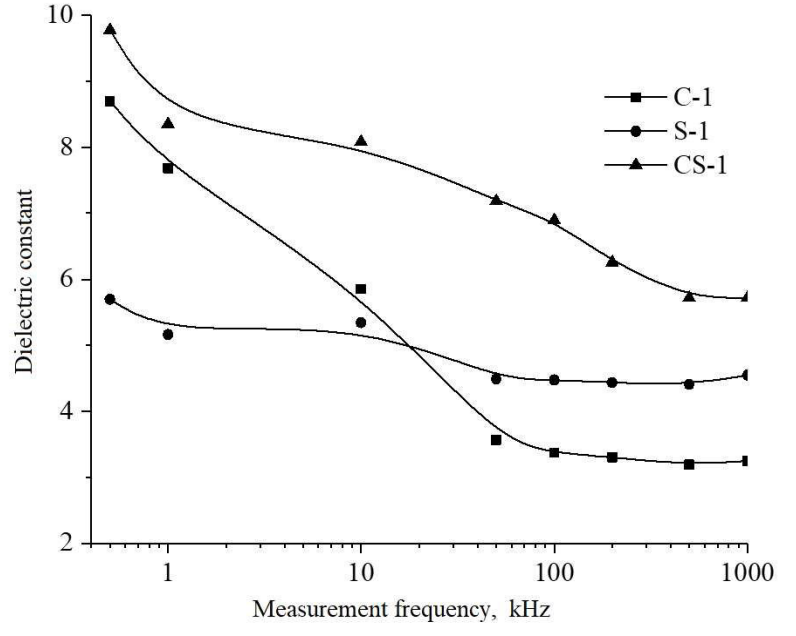

Fig. 5. Dependence of the dielectric constant of the samples on the measurement

Thus the exothermic synthesis of nanoand submicrocrystalline powders in the $\mathrm{RO}(\mathrm{R}=\mathrm{Ba}, \mathrm{Sr})-\mathrm{Al}_{2} \mathrm{O}_{3}-\mathrm{SiO}_{2}$ system and the resulting ceramic materials on their basis can be used in the manufacture of protective structures for devices operating in epy radio frequency band and technical ceramic products (capacitors, inductors, electrical insulators, etc.) operating at elevated frequencies.

\section{Conclusions}

Ceramic materials were synthesized in the $\mathrm{RO}(\mathrm{R}=\mathrm{Ba}, \mathrm{Sr})-\mathrm{Al}_{2} \mathrm{O}_{3}-\mathrm{SiO}_{2}$ system using the technology of exothermic synthesis from solutions containing barium and strontium nitrates, silica and organic reducing agents (glycine and carbamide). It is shown that only the use of a mixture of glycine and carbamide as well as addition of ammonium nitrate allows carrying out an exothermic process with complete conversion of the initial components. 
In this case, an X-ray amorphous product with a small fraction of the crystalline phase is formed. During heat treatment of the product obtained during exothermic synthesis, crystalline phases of barium and strontium aluminosilicates $\left(\mathrm{BaAl}_{2} \mathrm{Si}_{2} \mathrm{O}_{8}\right.$ and $\mathrm{SrAl}_{2} \mathrm{Si}_{2} \mathrm{O}_{8}$ ) are formed. The structure of the material is highly porous with different sizes of crystalline aggregates of irregular shape, with the crystallite size being about $20-50 \mathrm{~nm}$.

The highest degree of sintering at the temperature of $1550^{\circ} \mathrm{C}$ is inherent in the material obtained on the basis of the composition CS-11, its open porosity is $0-1.0 \%$ and compressive strength is $115 \mathrm{MPa}$. Compositions $\mathrm{C}-1$ and $\mathrm{S}-1$ sintered at this temperature exhibit an open porosity of the order of $11-12 \%$. It is shown that the dielectric constant of the obtained samples is $3.25-6.0$ at the frequency of $1 \mathrm{MHz}$, the minimum values correspond to ceramics based on barium aluminosilicate. The dielectric loss tangent $(\operatorname{tg} \delta)$ at the frequency of 1 $\mathrm{MHz}$ is $(1.5-5.2) \cdot 10^{-3}$.

Thus, there is the possibility to use the exothermic synthesis technology to fabricate nanoand submicrocrystalline powders in the $\mathrm{RO}(\mathrm{R}=\mathrm{Ba}, \mathrm{Sr})-\mathrm{Al}_{2} \mathrm{O}_{3}-\mathrm{SiO}_{2}$ system. Materials based on the obtained aluminosilicates can be used in the production of technical ceramic.

\section{Acknowledgments}

This work was financially supported by the grant T19UKRG-004 of the BRFFR and the State Committee for Science and Technology of Belarus.

\section{REFERENCES}

1. Высокотемпературные радиопрозрачные материалы: сегодня и завтра / Уварова Н.Е., Гращенков Д.В., Исаева Н.В. и др. // Авиационные материалы и технологии. 2010. - № 1. - C.16-21.

2. Михеев С.В., Строганов Г.Б., Ромашин А.Г. Керамические и композиционные материалы в авиационной технике. - М.: Альтекс, 2002. - 275 с.

3. Современные достижения в области создания высокотемпературных радиопрозрачных материалов / Саркисов П.Д., Гращенков Д.В., Орлова Л.А. и др. // Техника и технология силикатов. - 2009. - Т.16. - № 1. - С.2-10.

4. Суздальцев Е.И. Керамические радиопрозрачные материалы: вчера, сегодня, завтра / Новые огнеупоры. 2014. - № 10. - C.5-18.

5. Ивахненко Ю.А., Варрик Н.М., Максимов В.Г. Высокотемпературные радиопрозрачные керамические композиционные материалы для обтекателей антенн и других изделий авиационной техники (обзор) / Труды ВИАМ. - 2016. № 5. - C.36-43.
6. Технологические аспекты создания радиопрозрачных стеклокристаллических материалов на основе высокотемпературных алюмосиликатных систем (обзор) / Чайникова А.С., Ваганова М.Л., Щеголева Н.Е., Лебедева Ю.Е. // Труды ВИАМ. - 2015. - № 11. - С.26-39.

7. Influence of complex activators of sintering on creating radiotransparent ceramics in $\mathrm{SrO}-\mathrm{Al}_{2} \mathrm{O}_{3}-\mathrm{SiO}_{2} /$ Lisachuk G., Krivobok R., Zakharov A., Tsovma V., Lapuzina O. // East. Eur. J. Enterprise Technol. - 2017. - Vol.1(6-85). - P.10-15.

8. Савчук Г.К., Петроченко Т.П., Климза А.А. Получение и диэлектрические свойства цельзиановой керамики на основе гексагональной модификации $\mathrm{BaAl}_{2} \mathrm{Si}_{2} \mathrm{O}_{8} /$ Неорг. матер. - 2013. - Т.49. - № 6. - С.674-679.

9. Электрические свойства корундо-циркониевой керамики / Анненков Ю.М., Кабышев А.В., Ивашутенко А.С., Власов И.В. // Известия Томского политехн. ун-та. - 2005. - Т.308. - № 7. - C.35-38.

10. Riedel R., Chen I.W. Ceramics science and technology, volume 2: materials and properties. - Wiley, 2015. $-888 \mathrm{p}$.

11. Ceramic radiotransparent materials on the basis of $\mathrm{BaO}-\mathrm{Al}_{2} \mathrm{O}_{3}-\mathrm{SiO}_{2}$ and $\mathrm{SrO}-\mathrm{Al}_{2} \mathrm{O}_{3}-\mathrm{SiO}_{2}$ systems / Lisachuk G.V., Krivobok R.V., Fedorenko E.Yu., Zakharov A.V. // Epitoanyag-J. Silic.-Based Compos. Mater. - 2015. - Vol.67. - No. 1. - P.20-23.

12. Solid-state synthesis of ceramics in the $\mathrm{BaO}-\mathrm{SrO}-\mathrm{Al}_{2} \mathrm{O}_{3}-\mathrm{SiO}_{2}$ system / Fu Y.-P., Chang C.-C., Lin C.-H., Chin T.-S. // Ceram. Int. - 2004. - Vol.30. - No. 1. - P.41-45.

13. Optimization of the compositions area of radiotransparent ceramic in the $\mathrm{SrO}-\mathrm{Al}_{2} \mathrm{O}_{3}-\mathrm{SiO}_{2}$ system / Lisachuk G.V., Krivobok R.V., Dajneko K.B., et al. // Przeglad Elektrotechniczny. - 2017. - Vol.93. - No. 3. - P.79-82.

14. Development of new compositions of ceramic masses in $\mathrm{SrO}-\mathrm{Al}_{2} \mathrm{O}_{3}-\mathrm{SiO}_{2}$ system / Lisachuk G.V., Kryvobok R.V., Zakharov A.V., Chefranov E.V., Lisachuk L.N. // Funct. Mater. - 2017. - Vol.24. - No. 1. - P.162-167.

Received 17.04.2021

\section{ЕКЗОТЕРМІЧНИЙ СИНТЕЗ КЕРАМІЧНИХ МАТЕРІАЛІВ НА ОСНОВІ АЛЮМОСИЛІКАТІВ БАРІЮ I СТРОНЦІЮ}

К.Б. Подболотов, О.Т. Волочко, Г.В. Лісачук, Р.В. Кривобок, В.В. Волощук

Проведено синтез керамічних матеріалів в системі $\mathrm{RO}(\mathrm{R}=\mathrm{Ba}, \mathrm{Sr})-\mathrm{Al}_{2} \mathrm{O}_{3}-\mathrm{SiO}_{2}$ при застосуванні технології екзотермічної синтезу з розчинів, що включають нітрати барію і стронцію, кремнезем і органічний відновник (гліцин і карбамід). Показано, що тільки при використанні суміші гліцину і карбаміду, а також добавки нітрату амонію можливе здійснення повного екзотермічної синтезу з формуванням рентгеноаморфного продукту з малою часткою кристалічної фази. Встановлено формування монофазних матеріалів на основі алюмосилікатів барію $\left(\mathrm{BaAl}_{2} \mathrm{Si}_{2} \mathrm{O}_{8}\right)$ і стронцію $\left(\mathrm{SrAl}_{2} \mathrm{Si}_{2} \mathrm{O}_{8}\right)$ термообробкою отриманого рентгеноаморфного продукту при температурі понад $1000^{\circ} \mathrm{C}$. Кераміка з синтезованих матеріалів, спечена при температурі $1550^{\circ} \mathrm{C}$, характеризується високою вогнетривкістю, відкритою порис- 
тістю 0-1,0\%, міцністю при стисканні 115-120 МПа, діелектричної проникністю 3,25-6,0 (при частоті 1 МГц) і тангенсом кута діелектричних втрат $(1,5-5,2) \cdot 10^{-3}$. Показана можливість застосування технології екзотермічного синтезу для одержання нано- та субмікрокристалічних порошків в системі $\mathrm{RO}(\mathrm{R}=\mathrm{Ba}, \mathrm{Sr})-\mathrm{Al}_{2} \mathrm{O}_{3}-\mathrm{SiO}_{2}$. Матеріали на основі одержаних алюмосилікатів можуть бути використані при виготовленні захисних конструкцій пристроїв, що працюють в радіодіапазоні, для радіолокаційних установок авіаційної і ракетної техніки, СВЧ-елементів, тощо.

Ключові слова: радіопрозора кераміка, славсоніт, цельзіан, мікроструктура, діелектрична проникність, тангенс діелектричних втрат.

\section{EXOTHERMIC SYNTHESIS OF CERAMIC MATERIALS BASED ON BARIUM AND STRONTIUM ALUMINOSILICATES}

\author{
K.B. Podbolotov ${ }^{a}$, A.T. Volochko ${ }^{a}$, G.V. Lisachuk ${ }^{b}$, \\ R.V. Krivobok ${ }^{b}$, V.V. Voloshchuk ${ }^{b, *}$
}

a Physical and Technical Institute of the National Academy of Sciences of Belarus, Minsk, Republic of Belarus

b National Technical University «Kharkiv Polytechnic Institute», Kharkiv, Ukraine

*e-mail: valenty93vol@gmail.com

Ceramic materials were synthesized in the $\mathrm{RO}(\mathrm{R}=\mathrm{Ba}, \mathrm{Sr})^{-}$ $\mathrm{Al}_{2} \mathrm{O}_{3}-\mathrm{SiO}_{2}$ system using exothermic synthesis from solutions containing barium and strontium nitrates, silica and organic reducing agents (glycine and carbamide). It was shown that only the use of a mixture of glycine and carbamide as well as the addition of ammonium nitrate allows carrying out a complete exothermic synthesis with the formation of an X-ray amorphous product with a small fraction of the crystalline phase. It was established that monophase materials based on barium and strontium aluminosilicates $\left(\mathrm{BaAl}_{2} \mathrm{Si}_{2} \mathrm{O}_{8}\right.$ and $\left.\mathrm{SrAl}_{2} \mathrm{Si}_{2} \mathrm{O}_{8}\right)$ are formed when the obtained $\mathrm{X}$-ray amorphous product is heat-treated at the temperatures above $1000^{\circ} \mathrm{C}$. Ceramics from synthesized materials sintered at $1550^{\circ} \mathrm{C}$ has a high refractoriness, open porosity of $0-1.0 \%$, compressive strength of $115-120 \mathrm{MPa}$; dielectric constant of 3.25-6.0 (at the frequency of $1 \mathrm{MHz}$ ) and the loss tangent of $(1.5-5.2) \cdot 10^{-3}$. The results shows that the exothermic synthesis ensures the preparation of nano- and sub-microcrystalline powders in the system $\mathrm{RO}(\mathrm{R}=\mathrm{Ba}, \mathrm{Sr})-\mathrm{Al}_{2} \mathrm{O}_{3}-\mathrm{SiO}_{2}$. Materials based on the obtained aluminosilicates can be used in the manufacture of protective structures for devices operating in the radio frequency band, in radar installations of aviation and rocket technology, in microwave elements, etc.

Keywords: radiotransparent ceramics; slavsonite; celsian; microstructure; dielectric constant; dielectric loss tangent.

\section{REFERENCES}

1. Uvarova NE, Grashhenkov DV, Isaeva NV, Isaeva NV, Orlova LA, Sarkisov PD. Vysokotemperaturnye radioprozrachnye materialy: segodnja i zavtra [High-temperature radiotransparent materials: today and tomorrow]. Aviatsionnye Materialy $i$ Tekhnologii. 2010; (1): 16-21. (in Russian).

2. Mikheev S.V., Stroganov G.B., Romashin A.G. Keramicheskie i kompozitsionnye materialy $v$ aviatsionnoi tekhnike [Ceramic and composite materials in aircraft industry]. Moscow: Al'teks; 2002. 275 p. (in Russian).
3. Sarkisov PD, Grashchenkov DV, Orlova LA, Uvarova NE, Popovich NV. Sovremennye dostizheniya v oblasti sozdaniya vysokotemperaturnykh radioprozrachnykh materialov [Up-to-date achievements in the field of development of high-temperature radiotransparent materials]. Tekhnika i Tekhnologiya Silikatov. 2009; 16(1): 2-10. (in Russian).

4. Suzdal'tsev EI. Keramicheskie radioprozrachnye materialy: vchera, segodnya, zavtra [Ceramic radiotransparent materials: yesterday, today and tomorrow]. Novye Ogneupory. 2014; (10): 5-18. (in Russian).

5. Ivakhnenko YuA, Varrik NM, Maksimov VG. Vysokotemperaturnye radioprozrachnye keramicheskie kompozitsionnye materialy dlya obtekateley antenn i drugikh izdeliy aviatsionnoy tekhniki (obzor) [High-temperature radiotransparent ceramic composite materials for antenna domes and other items of aircraft industry (a review)]. Trudy VIAM. 2016; (5): 36-43. (in Russian).

doi: 10.18577/2307-6046-2016-0-5-5-5.

6. Chaynikova AS, Vaganova ML, Shchegoleva NE, Lebedeva YuE. Tekhnologicheskie aspekty sozdaniya radioprozrachnykh steklokristallicheskikh materialov na osnove vysokotemperaturnykh alyumosilikatnykh sistem (obzor). Trudy VIAM. 2015; (11): 26-39. (in Russian).

doi: 10.18577/2307-6046-2015-0-11-4-4.

7. Lisachuk G, Krivobok R, Zakharov A, Tsovma V, Lapuzina $\mathrm{O}$. Influence of complex activators of sintering on creating radiotransparent ceramics in $\mathrm{SrO}-\mathrm{Al}_{2} \mathrm{O}_{3}-\mathrm{SiO}_{2}$. East Eur $J$ Enterprise Technol. 2017; 1 (6): 10-15.

doi: $10.15587 / 1729-4061.2017 .91110$.

8. Savchuk GK, Petrochenko TP, Klimza AA. Preparation and dielectric properties of celsian ceramics based on hexagonal $\mathrm{BaAl}_{2} \mathrm{Si}_{2} \mathrm{O}_{8}$. Inorg Mater. 2013. 49: 632-637.

doi: $10.1134 / \mathrm{S} 0020168513060101$.

9. Annenkov YuM, Kabyshev AV, Ivashutenko AS, Vlasov IV. Elektricheskie svoistva korundo-tsirkonievoi keramiki [Electrical properties of zirconia alumina ceramics]. Izvestiva TPU. 2005; 308(7): 35-38. (in Russian).

10. Riedel R, Chen IW, editors. Ceramics science and technology, volume 2: materials and properties. Wiley; 2015. 888 p.

11. Lisachuk GV, Krivobok RV, Fedorenko EY, Zakharov AV. Ceramic radiotransparent materials on the basis of $\mathrm{BaO}-\mathrm{Al}_{2} \mathrm{O}_{3}-\mathrm{SiO}_{2}$ and $\mathrm{SrO}-\mathrm{Al}_{2} \mathrm{O}_{3}-\mathrm{SiO}_{2}$ systems. Epitoanyag Journal of Silicate Based and Composite Materials. 2015; 67(1): 20-23. doi: 10.14382/epitoanyag-jsbcm.2015.4.

12. Fu YP, Chang CC, Lin $\mathrm{CH}$, Chin TS. Solid-state synthesis of ceramics in the $\mathrm{BaO}-\mathrm{SrO}-\mathrm{Al}_{2} \mathrm{O}_{3}-\mathrm{SiO}_{2}$ system. Ceram Int. 2004; 30: 41-45. doi: 10.1016/S0272-8842(03)00059-2.

13. Lisachuk GV, Kryvobok RV, Dajneko KB, Zakharov AV, Fedorenko EY, Prytkina MS, et al. Optimization of the compositions area of radiotransparent ceramic in the $\mathrm{SrO}-\mathrm{Al}_{2} \mathrm{O}_{3}-\mathrm{SiO}_{2}$ system. Przeglad Elektrotechniczny. 2017; 93(3): 79-82. doi: 10.15199/48.2017.03.19.

14. Lisachuk GV, Kryvobok RV, Zakharov AV, Chefranov EV, Lisachuk LN. Development of new compositions of ceramic masses in $\mathrm{SrO}-\mathrm{Al}_{2} \mathrm{O}_{3}-\mathrm{SiO}_{2}$ system. Funct Mater. 2017; 24(1): 162-167. doi: 10.15407/fm24.01.162. 